\title{
Father Louis Funcken's Contribution to German Catholicism in Waterloo County, Ontario
}

\author{
James A. Wahl
}

Volume 50, numéro 2, 1983

Bilan de l'histoire religieuse au Canada

Canadian Catholic History: A survey

URI : https://id.erudit.org/iderudit/1007220ar

DOI : https://doi.org/10.7202/1007220ar

Aller au sommaire du numéro

Éditeur(s)

Les Éditions Historia Ecclesiæ Catholicæ Canadensis Inc.

ISSN

0318-6172 (imprimé)

1927-7067 (numérique)

Découvrir la revue

Citer cet article

Wahl, J. A. (1983). Father Louis Funcken's Contribution to German Catholicism in Waterloo County, Ontario. Sessions d'étude - Société canadienne d'histoire de l'Église catholique, 50(2), 513-531. https://doi.org/10.7202/1007220ar

Tous droits réservés @ Les Éditions Historia Ecclesiæ Catholicæ Canadensis Inc., 1983
Ce document est protégé par la loi sur le droit d'auteur. L'utilisation des services d’Érudit (y compris la reproduction) est assujettie à sa politique d'utilisation que vous pouvez consulter en ligne.

https://apropos.erudit.org/fr/usagers/politique-dutilisation/ 


\title{
Father Louis Funcken's Contribution to German Catholicism in Waterloo County, Ontario
}

\author{
by James A. WAHL, C.R. \\ St. Jerome's College, University of Waterloo
}

In 1857 Bishop Armand de Charbonnel, the second Bishop of Toronto, was in Rome seeking missionaries for his diocese as well as for the dioceses of London and Hamilton which had been newly (February 15, 1856) created out of the western portion of Toronto. That the need was great is evidenced by the fact that Bishop John Farrell of Hamilton had only eight priests, four of them Jesuits located in Guelph, to provide care for an extensive diocese containing some 28,000 Catholics! One of these, Fr. John Holzer, S.J., had written his brother in Austria describing the desperate need for priests, particularly in and around Waterloo County where approximately 12,000 German-speaking Catholics had established an organized but priestless community. "What", he wrote, "are so many able and learned men doing there with you in your universities, when here so many souls are lost... Before all else we must establish Catholic schools else we shall lose the Catholic youth." '

It is therefore not surprising that Bishop de Charbonnel's quest should specifically include German-speaking priests. Thus, when he heard of a new Congregation of priests he approached them with his problem. What the good Bishop did not know was that this community, the Congregation of the Resurrection, which had begun its vowed life on Easter Sunday in 1842, had, to that time, been composed entirely of Polish emigres whose ministry was restricted completely to the Polish emigre population. While a few of these priests spoke

\footnotetext{
${ }^{1}$ See K. Foyster, Anniversary Reflections: 1856-1981: A History of the Hamilton Diocese, pp. 19-20.
} 
German their sympathies were decidedly not in the direction of a Teutonic ministry. Had the Bishc, known this he may well have decided not to make the approach but his ignorance was providential because fortunately there was one non-Pole on the verge of ordination, a Rhenish-Prussian from Wanckum, Eugene Funcken, who had, almost by accident joined the community in 1852 . In truth his very presence in the community had been greeted with less than enthusiasm and one of the members of the little group had written to the General Fr. Jerome Kajsiewicz warning against the German spirit. ${ }^{2}$

Even when Charbonnel's request was made there was some hesitation; after all the community was only some eighteen strong, only nine of whom were priests and of these only eight were finally professed. As Fr. Jerome described it in a letter: 'The kind Bishop of Toronto, Charbonnel, has asked us to give him some missionaries for his Bohemian and German colonists, offering us a church with a monastery and land. When they (the council) vacillated as to what could be done here and now I begged to give him at least a priest who could occupy the house until others could come. After thinking it over we offered him Brother Eugene Funcken already a subdeacon and Glowacki, a Silesian. ${ }^{3}$ I think it is safe to say that part of the thinking over, the discernment, may well have focussed on the effectiveness and indeed appropriateness of Fr. Eugene's ministering to Poles. In fact Fr. Jelowicki gloomily prophesied that these recruits 'one German, and the other a self-styled Pole but who knows he is not a Pole, will found for themselves a regime separated from us.' ${ }^{4}$ Such an attitude hardly boded well for a ministry by a German to Poles! Whether or not the thinking was as I have described it, Fr. Eugene Funcken, newly ordained, and cleric Edward Glowacki set sail for North America, arriving at St. Agatha, Ontario on August 14, 1858. The arrival of these men marked the beginning of the Resurrectionist apostolate in North America and was the first step towards the subsequent life work of Fr. Louis Funcken of whom we are speaking today.

Fr. Eugene's pastoral concern embraced all age levels and he showed particular care for the youth. From the very beginning of his apostolate

\footnotetext{
${ }^{2}$ See Paul Smolikowski, Excerpts from the History of the Congregation of the Resurrection of our Lord Jesus Christ, trans. J.A. Wahl (private printing), Waterloo, 1980 , p. 5.

${ }^{3}$ Ibid., p. 4.

${ }^{4}$ Ibid., p. 5.
} 
the education of children was a high priority. In September 1858 he opened a small school in his rectory with the aid of David Fennessy an Irish seminarian who had been sent to Fr. Eugene to learn German. Fennessy's departure for the seminary in Montreal, and Fr. Eugene's constant involvement in other parochial duties forced the abandonment of this first effort but Fr. Eugene was determined to provide education for his youth.

To achieve this end Fr. Eugene began to contemplate the possibility of having his younger brother Louis, already studying at the seminary at Roermond, Holland, take charge of this very important area of the apostolate in St. Agatha. Unfortunately, from Eugene's point of view, his brother was not considering entering the Congregation but was studying for the diocese of Roermond, and in 1862 was ordained for that diocese. Eugene was able to attend the ordination as part of a fund raising trip to Europe. On his way back from this trip Eugene again stopped off to see his brother only to find that Louis was suffering severe headaches and periods of despondency. Together they travelled to Ostend to consult a doctor and to see about the possibility of Fr. Louis joining the Third Order of the Congregation of the Resurrection. The latter event did not materialize because the priest they wanted to see was not there but the consultation did take place and Fr. Louis was advised to seek a warm climate for the winter months. When Louis discussed this with his brother and another Resurrectionist, Fr. Alexander Jelowicki, then in Ostend, both immediately offered him the hospitality of the Congregation's house in Rome. Accepting gratefully, Louis arrived there in December of 1862 . It would be edifying to report that these offers flowed strictly from Christian and altruistic motives but, in fact, both men, in letters recommending Louis to the fathers in Rome, made it clear that their hope was that he might join the Congregation and Fr. Alexander even wrote openly of Louis joining his brother in Canada. All their prayers, hopes, and, perhaps, schemes came to fulfillment for, two years later, in June of $1864 \mathrm{Fr}$. Louis joined the Congregation and, as it happened that Fr. Eugene was also in Rome for a meeting of the General Council, he was able to travel to his new apostolate in the company of his older brother, arriving at St. Agatha on September 2, 1864.

Upon his arrival Fr. Louis found a predominantly German population, the Roman Catholics among them being primarily agricultural and skilled labourers. There were few Catholics in any leadership roles nor had there been any vocations to the priesthood in the area. Along with his brother Fr. Louis believed that education was the key to 
rectifying this situation. On January 1,1865 he opened the doors of St. Jerome's College in a rented $\log$ cabin about a half a mile east of the village of St. Agatha and began what would be his life work. Prior to the inauguration of his 'little log cabin' Louis had submitted a report to Bishop John Farrell outlining the curriculum he intended to follow, his aims, and the methods he intended to employ. In the latter area he was clear on one thing, informing the Bishop, 'we will try to have a familial spirit dominate; what is demanded of the students is obedience of the heart and mind; neither confinement nor caning will be used. On the contrary we will use:
a) remonstrations and corrections in private;
b) public corrections;
c) writing something out;
d) deprivation of some recreation;
e) an appearance before the fathers;
f) expulsion 5

All in all a rather modern approach to educational discipline.

When it came to the curriculum Fr. Louis was also prepared to deviate from commonly accepted norms. Convinced that the normal and strictly classical education then current would not inculcate a truly Christian perspective in his students Fr. Louis envisioned a system which would utilize Sacred Scripture, Christian classics (e.g. Augustine, Tertullian and Jerome), and pagan classics carefully edited so as to support the Christian thrust of the school. In this he was following the example of John Bosco whose schools for boys in Europe excited Louis' admiration as well as the Rule of the Congregation of the Resurrection (1850) No. 169, which insisted on the use of Christian writers:

In this way the minds of youth shall become impregnated with Christian truth; their imagination shall be directed to appreciate the incomparable beauty of divine truth, and a love of Christian good shall inflame their hearts. Examples from the classics shall be used for comparison in the advanced course of studies when the student is more mature.

Unfortunately, Fr. Louis' proposed curriculum failed to meet the admission requirements of the Universities of Toronto or Laval.

5 “'Report to Bishop Farrell,' October 28, 1864, Archives of the Diocese of Hamilton, unnumbered manuscript, p. 21. 
Consequently when at the suggestion of Bishop Farrell it was decided to move the College into Berlin, a town of 2,000, Fr. Louis also decided to bring the curriculum into line with the current requirements, abandoning the Christian classics, at least for the time being until more manpower and better texts were available. When he was reproached by the authorities of the Congregation in Rome for choosing this course of action Fr. Louis, in a long letter written on July 1, 1867 replied that he had not abandoned the idea entirely; he was still hopeful of producing an edition of the Christian and profane classics with notes in English and German, but this would have to wait for a time when the College was more stable and he had more opportunity. He further pointed out that he himself had come to appreciate the fact that his original concept was viable only when there was sufficient time and when the students themselves were receptive. His, he ruefully admitted, were not. As proof of this he related how it happened one day that he had not had time to prepare his lesson and instead had the students read from the Life of St. Anthony. When they came to the part where St. Paul of the Desert complimented himself on spending twelve hours in prayer with Anthony his pupils let out, as he put it, 'such an Homeric shout of laughter', that he was embarassed. When they were not laughing they found the Christian authors such as Jerome and Bede as dry as straw. For these reasons he concluded there was more to fear from being too Christian than from being less. In fact, he wrote in summation: 'should I attempt it my students would be liable to throw their books at my head.' ${ }^{6}$ Although this was no doubt an attempt at humerous hyperbole it was nevertheless obvious to Louis that the high educational ideals of the community based on a European and religious model would have to bend to the exigencies of the situation.

The transfer of the College to Berlin, where it opened its doors in October, 1866, inaugurated a new and important phase in its history. In addition to preparing students for higher studies in law, medicine, pharmacy, etc., a new dimension was now added, the education of young men in subjects which would benefit them in the context of Berlin's commercial life. Seeking financial assistance from the citizens of Berlin,

\footnotetext{
6 "Letters of Louis Funcken," Archives of the Congregation of the Resurrection in Rome (CRR), MS 13369, fol. 2.
} 
Fr. Eugene Funcken in a letter solliciting their support gave several reasons why such generosity might be expected:

It will probably increase the population of the town, as many families may choose Berlin for their residence on account of the College.

Parents will have an opportunity of giving their children a higher education.

Merchants will meet with ready and numerous customers for their goods.

Students from a distance may sometimes be allowed to board in the town.

It is the intention of the Rev. Gentlemen to give some lessons to the young men of the town, especially in Chemistry, which will be of immense advantage to the industrial class.

Besides these and other advantages the honour of the town will be enhanced by such an institution. ${ }^{7}$

Although this appeal was not particularly successful it did mark the beginning of a conscious effort to train young men in walks of life consistent with the needs of Berlin and environs. In the 'Statistical Synopsis' of the first year of operation Fr. Louis defined the scope of the College in the following words:

The institution is under the patronage of the Right Reverend Bishop of Hamilton, and is conducted by the Ecclesiastics of the Congregation of the Resurrection. Its object is to educate young men in the spirit of Christianity, and to prepare them by careful instruction for higher professional studies and for commercial or agricultural life, for which the students may be intended. 8

To achieve these goals, and to attract sufficient numbers of students, the College offered two courses of study: an academic programme of four years which prepared students for higher studies; and a commercial course of two years which prepared them for commercial life and could also serve as a preparation for the academic course if needed.

\footnotetext{
${ }^{7}$ Letter of Introduction, February 15, 1866 in The Letters of Eugene Funcken, ed. and trans. J.A. Wahl, Waterloo, 1982, $2: 2$, p. 28.

${ }^{8} \mathrm{~A}$ copy of this synopsis, in German, is in the Archives of the Congregation of the Resurrection in Ontario, and is currently on loan for display at St. Jerome's College.
} 
In addition to adapting the curriculum to meet the requirements of his students, Fr. Louis' pedagogy was also instrumental in preparing the students for the society in which they would find themselves. This was particularly true of those students who would enter the commercial and public life of Berlin. As the town began to grow its inhabitants became more and more conscious of its self-image. Time and again speeches portrayed Berlin as a community of industrious, thrifty, prosperous, law-abiding and harmonious people. On occasion St. Jerome's contribution to this quality of life was highlighted. In 1907, some seventeen years after the death of Fr. Louis, on the occasion of the laying of the cornerstone for the new addition to the College and the dedication of the Fr. Louis Funcken Memorial Statue Alderman F.W. Sheppard, speaking on behalf of the mayor and in the presence of the Apostolic Delegate and other dignitaries, painted the standard picture of Berlin and, as the occasion no doubt dictated, acknowledged the role played by the College and Fr. Louis:

In extending to you, Rev. and honourable gentlemen, this welcome, allow me briefly to place before you, in no boastful way, or vainglorious spirit, a Short sketch of this prosperous and fortunate Busy Berlin'.

It is a town of almost unparalled industrial and commercial activity and prosperity; a town of happy relations between capital and labour; a loyal, law-abiding, peace-loving, busy town; a town of homes and home life.

I would attribute then, to some extent at least, more than is usually done our prosperity to this ever-growing sense of unity, to a oneness of aim and of effort springing, I believe, largely from the broader minds and more brotherly hearts of men educated in the principles of a true and christian philosophy.

We therefore, as citizens of the town of Berlin, not only rejoice that St. Jerome's has kept pace with and participated in the general prosperity of this community, but we are also ready to credit it with contributing and helping to bring about this prosperity. ${ }^{9}$

9 "Civic Address" in The Saint Jerome Schoolman, Souvenir Number, X:1 (September 1907), pp. 18-19. 
The civic virtues of industriousness, loyalty, and domesticity which Berliners were wont to advertize were echoed in the life of St. Jerome's College under Fr. Louis. The principles upon which his system rested were love, trust and loyalty. His approach to education won the love and trust of his students and they became imbued with the same principles. Louis himself defined his system thus:

My system is this: the director ought to love his students; they must be persuaded of this; he must be concerned with their entire being and future... He ought to have a rule and have it observed not as an end but as a means of forming honest people. ${ }^{10}$

The cardinal point of discipline is charity, fraternal concern and mutual respect. "

It is interesting to note, however, that these and many similar declarations were made by way of apology because he was under fire for his methods. It is ironic that a system which seemed (and proved to be) destined to promote the best Christian values was severely criticized by some of the very people who wanted to achieve these goals. Two men who criticized him most severely on this point were Frs. Louis Elena, and David Fennessy both of whom joined Louis on the staff in 1866. Both of these men believed strongly in the use of authority and external rigour. Fr. Louis was adamant that severity was to be avoided and although he might use the cane, and even then rarely, on younger students, his ordinary procedure was to rely on friendly persuasion, using reason, appeals to the heart and even humour to win over a recalcitrant student. One of his students, John Fehrenbach, recalled Fr. Louis' methods vividly:

At the beginning of the school year he used to say to the students: 'There is but one rule in this house, and that is that there is no rule as long as things go well. Disorder only causes rules and laws; a little disorder, even, is better than too many rules.' He did not hesitate to break up the regular routine for a good reason. When late at table, prayers were omitted; the blessing was sufficient. It was not hard to obtain a longer sleep on cold winter mornings, or an occasional holiday. ${ }^{12}$

\footnotetext{
${ }^{10}$ Letter of January 11, 1870 to Jerome Kajsiewicz, (MS CRR 13379, fol. 12); also see Smolikowski, Excerpts, pp. 69-73; and J.A. Wahl, "Looking Back: Part 2" Resurrection Bulletin (RB) 20:1 (May, 1978), pp. 6-7.

${ }^{11}$ Letter to the General, 1 July 1867 (MS CRR 13369, fol. 3).

12 "'The Founder: Character Sketch" RB $2: 3$, p. 3.
} 
These gestures were, unfortunately, interpreted and reported to the authorities in Rome as examples of laxity of discipline and even moral laxity. These were no minor criticisms. The Superior General, Fr. Jerome Kajsiemwicz, was moved to write Fr. Eugene Funcken about his brother in 1869:

As long as Fr. Louis remains at the head of the College it will amount to nothing. A good heart is not sufficient for the direction of a College; ... Beg Fr. Louis to turn over the discipline to Fr. Elena. ${ }^{13}$

Tenaciously, and with the support of his brother and some of the older members of the mission, Louis resisted all efforts to change the nature of the methods used at the College. Fr. Eugene, particularly, defended his brother in a letter to Rome :

My brother's method is according to the Rule with which it is impregnated; he forms men and Christians while the others with their coldness would form, perhaps, machines. I know the young men think often of Fr. Louis with gratitude while they disregard all the others. ${ }^{14}$

When Fr. Eugene reluctantly showed his brother the letter he had received from the General, Louis responded point by point to the accusations raised against him. In a forthrightly aggressive letter he made it abundantly clear why Fr. Elena could never take over the direction of the College. He admitted that Elena was a good instructor and exceedingly regular in his religious observance of the Rule but this was possible because he did nothing outside of the classroom and teaching hours. For Fr. Louis, the apostolate went beyond the classroom to deal with students on an individual basis, helping them with their personal as well as their academic problems. He charged Elena with using the Rule to avoid any involvement beyond the classroom and went on to point out that Elena himself had admitted that he could not run the school.

When we examine Fr. Louis' struggles to defend the curriculum of his school and his methods of education in the face of the most strenuous opposition from many levels it becomes readily apparent that

\footnotetext{
${ }^{13}$ Letter of December 10, 1869 (MR CRR 7702, fol. 2).

${ }^{14}$ Letter dated end of January, beginning of February, 1870, Letters of Eugene Funcken, 2:3, p. 34.
} 
he conceived these as means to an end and that was simply to produce intelligent Christian leaders, not simply 'automatons' who would be leaders in the predominantly German society of Berlin and environs. ${ }^{15}$ At the same time this was an area within Upper Canada surrounded by an English-speaking population. To Fr. Louis it was evident that, while the preservation of their German culture and language was imperative for his German youth, the language of commerce and politics in general was English. Thus, although Fr. Louis himself spoke no English when he arrived, English and German were taught at the College and the Mathematics courses were taught in English as well. But to thrust of the college was to be German even though the students were expected to learn both languages. This point was emphasized in a petition for aid which was submitted to the Lieutenant Governor of Ontario, describing St. Jerome's as 'the German-English College... in which children may receive a complete course of instruction, in which German and English are taught together, and from which young men may go forth, who whether as belonging to the learned professions, or as merchants of mechanics, may be enabled by a knowledge of the two languages to keep up free intercourse with the inhabitants and to promote immigration from Germany.' 16 This attempt to secure the same government support which had been previously given to the other Englishspeaking institutions was heartily endorsed by the Berliner Journal as a way to preserve a German identity. ${ }^{17}$ But several factors led to a gradual shift in the emphasis at St. Jerome's so that by 1878 English was the primary language of instruction although, in the interest of

\footnotetext{
${ }^{15}$ See Fr. Louis' letter of 11 January, 1870 (MS CRR 13379, fol. 3) for his defense of his system. For a detailed examination of this see Paul Smolikowski, "The Spirit of Fr. Louis and his Views on Christian Education, as found in his Correspondence", The Schoolman, XVII:4 (June, 1915), pp. 194-205. In their new book, J.R. English and K.M. McLaughlin point out: "The businessmen of Berlin were its first and natural leaders." Kitchener: An Illustrated Hystory, Waterloo, Wilfrid Laurier Press, 1983, p. 50 .

16 “Personal Papers and Documents of Louis Funcken", Archives of the Congregation of the Resurrection in Ontario (CRO).

17 " The days are over when the recent immigration from Germany was looked upon with disdain. It is unthinkable that we sit idly by while the Germans are prevented from learning German and while other ethnic groups receive grants in education. Nor are we going to submit to moral pressure by conveniently forgetting our mother tongue." Berliner Journal, 13 November, 1867; see G. Leibbrandt, Little Paradise, Kitchener, Allprint Co., Ltd., 1980, pp. 85-89; also English and McLaughlin, pp. 34$36 ; 75$.
} 
preserving the German culture, the language of conversation was alternately German and English. ${ }^{18}$

Fr. Louis' determination to produce a learned German Catholic community was not shared by all. In fact the Germans of Waterloo County were not all that enthusiastic. Writing in 1916, Fr. Theobald Spetz commented:

It $\mid$ St. Jerome's College $\mid$ also gave the youth of Berlin and the neighbourhood an opportunity to gain a better Catholic education at small cost. Unfortunately the Catholics of the neighbourhood have not made use of this opportunity as fully as they should.

Parents generally put their boys too soon to remunerative work instead of trying to secure for them a better education and thus providing them with the chance of securing a share of the better positions and greater usefulness towards the community. ${ }^{19}$

This reluctance is evident in the fact that from the beginning Fr. Louis had to take in American students and non-Germans from Canada to secure a sufficient number of students. In $1884 \mathrm{Fr}$. Louis was considering abolishing Christmas holidays (for reasons unknown) and the entire class signed a petition asking that he honour the clause in the circular for the year that 'There will be a short recess at Christmas.' An analysis of the signatures and comparison with information given in the 1890 Alumni Association listing ${ }^{2 n}$ indicates that only two students can be identified certainly as being from Berlin, five from the 'neighbourhood', only one of which can be definitely identified as German. Of the remaining forty students twenty-six were Americans, seven are unidentified but none seem to have been from Berlin and only one as a distinctly German name, and the remaining seven come from more distant areas in Ontario; all of these and many of the others became priests or were studying for the priesthood and had been sent to the College by their Bishops.

\footnotetext{
${ }^{18}$ Louis Funcken to Lynch May 1, 1879, fol. 2. Archives, Archdiocese of Toronto, Archbishop Lynch Papers.

${ }^{19}$ Theobald Spetz, The Catholic Church in Waterloo County, Toronto, The Catholic Register and Extension, 1916, p. 133.

${ }^{20}$ Report of the Seventh General Meeting of the Alumni Union of St. Jerome's College, June 26th, 1890, pp. 7-13. Personal Papers and Documents of Louis Funcken, CRO.
} 
The idyllic picture of harmonious ethnic relations in Berlin at least until the catalyst of the First World War can no longer be accepted at face value. ${ }^{21}$ Ethnic divisions reared their heads within the confines of the College. As early as $1870 \mathrm{Fr}$. Louis told the General of an incident which had occurred while Fr. Elena was in charge during Louis' absence in Toronto: 'When I returned I found a terrible quarrel between the Germans and the Irish which lasted up to the time the youngsters left.' ${ }^{22}$ This division along ethnic lines is highlighted in a undated note found among Fr. Louis' papers in the Archives of the Congregation of the Resurrection in Waterloo:

\begin{abstract}
We don't like to have a thief for our prefect (these words crossed out) neither do we like to see Spalding, Kosienski or Reishwine with the prize of good conduct; those three fellows didn't deserve this prize. Kehoe is our man; but he is an Irishman and a good deal better than those two Duchmen and your little Pole. Mind this! If he, Kehoe, will not get the prize then all our English and Irish won't come any more. Mind this for the following year. N.N.N.H. Schl. ${ }^{23}$
\end{abstract}

In addition to such prejudices as these Fr. Louis' desire to maintain a German language institution was not viewed with approval by the newly appointed County School Inspector, Thomas Pierce, who was opposed to German - language schools and considered German a foreign language. In 1873 he reported, with disapproval, that Berlin students in the three higher departments were being taught in German. ${ }^{24}$ As a result of all these factors English became the primary language at the College. However, into the twentieth century one of the most important societies within the College was the St. Ludwig's Literarischer Verein whose members were 'given to a special culture of the German language.'

\footnotetext{
${ }^{21}$ It was during the First World War that Berlin's name was changed to Kitchener amid scenes of mob violence and "hatred and suspicion on the part of the English extremists." Leibbrandt, Little Paradise, pp. 245-55. However, as far back as 1871, at the time of the 'Friedensfest' in Berlin celebrating Germany's victory there is evidence of concern if not opposition. In a letter written by Eugene Funcken on May 1 to Louis we read this enigmatic statement: "With regard to the peace celebrations, he [Bishop Farrell] believes it would not be adviseable for us to give a speech. I am completely of the same opinion, especially after the vox populi which I have heard. I have therefore resolved to excuse myself. I will make a sick call or not be well myself depending on the weather." Letters of Eugene Funcken, 2:3, p. 64.

22 Letter to the General, 11 January, 1870, MS CRR 13379, fol. 2.

${ }^{23}$ CRO. Personal Papers and Documents of Louis Funcken.

${ }^{24}$ See Patricia McKegney. "The German Schools of Waterloo County: 1851-1913", Waterloo Historical Society, 58 (1970), pp. 54-67, at p. 58.
} 
With the opening of St. Mary's College, Kentucky, in 1871 a redeployment of personnel was demanded with the result that Fr. Louis found himself the only priest at St. Jerome's. He was also, as he had been since 1866, pastor of St. Mary's Church as well. Since his English was still not as fluent as he wished he utilized a public school teacher and some of his advanced students to carry on the work at the College. The years from 1871 to 1878 were years of trial and struggle as the number of students declined so that there were no more than twenty or twenty-five in any given year. Suggestions began to be made in Rome that the College be abandoned in favour of St. Mary's or a school in Chicago; but Louis was convinced that his work for the German Catholics was of the greatest importance for the Church. Another reason for Louis' stubborn refusal to give up on the College was his now growing expectation that he would be joined by some of his former students who were joining the Congregation. The foremost of these was Theobald Spetz, one of Louis' first students who had left for Rome in 1872 where he had been joined by William Kloepfer. Fr. Louis made it very plain to his Superiors that he expected these men to return to St. Jerome's because it was only just and furthermore the Bishop of Hamilton had always expected that as well. The justice of Fr. Louis' demands sprang from the fact that he had worked long and hard to produce such men and to deny them, native sons and German-English speaking ones at that, to the mission could only testify to a desire in Rome to destroy the mission in Canada. ${ }^{25}$

Fr. Louis' interpretation of the motives of the authorities in Rome was not without foundation. In 1871/2 a strange, even bizarre occurrence seriously undermined relations between Rome and the North American apostolate. The Chapter of 1871/2 was convened under the impression that it would be a swift meeting whose priorities would be to re-elect Fr. Kajsiewicz as Superior General, a foregone conclusion, which in fact did occur, and to prepare the Rule, composed in 1850, for presentation to the Holy See for approbation. Unfortunately the latter procedures did not go according to plan. In the midst of the deliberations Mother Marcelline Darowska, highly regarded and acknowledged as a visionary by Frs. Kajsiewicz, Peter Semenenko and the newly elected Assistant General Fr. Julian Felinski, intervened in an electrifying way; she sent the Capitular Fathers a copy of a Rule which she said she

\footnotetext{
${ }^{25}$ See Louis' letters to Fr. Julian Felinski, the Assistant General, dated 14 September, 1875 (MS CRR 13421) and 1 October, 1876 (MS CRR 13427, fol. 2).
} 
had received from God and which, she also claimed, they were to accept without change. Even more strangely, the Fathers acceded to her demands:

...there were close ties between Mother Darowska's community, the Immaculate Conception Sisters, and the Resurrectionists, and such close bonds were considered signs of divine favour. The Rule of 1850 which was being rejected was the work of Fr. Peter who, although his instincts said otherwise, agreed to the substitution to avoid a schism between the two communities. The New Rule stressed self-denial, renunciation, and mortification and, by interpretation at least, the premise emerged that the strict observance of the Rule was an end in itself. In general the Rule of 1872 can be described as a European creation encompassing a less active and more contemplative view of the apostolic thrust of the Congregation. Despite severe misgivings about the reception the new Rule would receive back in America and dubious about its adaptability to the active missionary apostolate, Fr. Eugene decided to cast his vote 'for the fathers', thereby indicating his reservations without causing overt dissension. ${ }^{26}$

Fr. Eugene's fears proved sound as the Rule was received with reactions varying from obedient acceptance to outright rejection. For his part, Fr. Louis adopted a wait and see attitude trusting in the fact that Fr. Kajsiewicz knew the situation in North America, having paid the mission two visits in 1865 and 1871, and was an able administrator. But on 26 February, 1873 the situation was altered as Fr. Jerome died suddenly and the emergency chapter convened to elect a new General turned to Fr. Peter Semenenko, the last of the Founders. While highly regarded as a spiritual leader and a profoundly holy man Fr. Peter had had no experience in the parochial and educational apostolate nor any first-hand knowledge of the North American scene. Since he was not an administrator much of the policy making began to be taken up by the Assistant General Fr. Felinski. He, too, was unfamiliar with the missions but even more upsetting, he was convinced that the Congregation was called, in the first instance, to minister to Poland as he informed Fr. Louis in a letter of 1 December, 1874:

The fact is that we have a sacred duty toward Poland and if we renounce it it would be suicide on our part because the needs of Poland are for today the principle reason for the existence of the Congregation. ${ }^{27}$

${ }^{26}$ J.A. Wahl, "Looking Back : Part 3" RB 20 :2, pp. 4-5.

${ }^{27}$ MS CRR 36540, fol. 1 . 
His conviction in this regard led him to the opinion that no further personnel should be committed to North America and that some apostolates be abandoned in order to concentrate their efforts. He began to campaign for the closure of St. Jerome's and its transfer to Chicago where the ministry was to American Poles. Given these circumstances it is obvious why Fr. Louis insisted so strenuously on the return of his two students (Spetz and Kloepfer) and in letter after letter to Fr. Eugene, Fr. Peter and Fr. Felinski reiterated this position. Should Fr. Julian's views be accepted it would mean the end of the German apostolate.

Fortunately Fr. Peter was unwilling to take such a drastic step and this together with Fr. Eugene and Louis' continuous campaign on behalf of the Canadian mission finally won the day. In $1878 \mathrm{Fr}$. Theobald Spetz returned to the College, to be followed the next year by William Kloepfer. For Louis and his dream it was the dawn of the new day! In 1878 Louis was able to contemplate the successes of his programme to that time within the perspective of a secure future. He issued a report to Archbishop Lynch of Toronto and the Bishops and priests of Ontario in which he reviewed the achievements of the past, outlined the curriculum and listed the staff for the following year, one of whom was Fr. Kloepfer. The report is clearly a proclamation of vindication:

I) Although the College is quite young, the results of our labours may be called satisfactory; viz.

1) 22 Theologians, of whom 8 are priests and one subdeacon.

2) 4 students of medicine of whom 2 are Doctors.

3 ) 5 students of law, of whom 3 are barristers.

4) One school inspector, 3 music teachers and 4 school teachers.

II) The exclusive aim of the College is the preparation of students for clerical seminaries and professional branches. Hence only carefully selected young men are admitted. We try to rule them by religion, honor and love.

III) All the branches of our program are taught in the English language; nevertheless, the conversational language is alternately German and English.

IV) At the next scholastic year we will be five teachers; viz. 3 priests, of whom two are born Canadians, having made their higher studies at the University of Rome; one English first class teacher; one music teacher. ${ }^{28}$

\footnotetext{
${ }^{28}$ Louis Funcken to Lynch May 1, 1879. Archives, Archives of Toronto, Archbishop Lynch Papers; also M. Godin and J.A. Wahl, "The Contribution of St. Jerome's College to 'Busy Berlin'”, Waterloo Historical Society, 70, (1982), pp. 21-22.
} 
Finally, after fifteen years of struggle and untiring resistance against those whom he perceived as being opposed to or ignorant of, the goals he was striving to achieve, Fr. Louis was now able to experience the fruits of his labours. He began to see many of his former students attaining positions of importance and leadership. As one former student of Louis, John A. Rittinger himself a Protestant and editor of Die Glocke in Walkerton, Ontario, wrote in his eulogy to his former mentor on February 15, 1890 :

\begin{abstract}
Honest and sincere in his convictions, tolerant toward his fellow Christians of other denominations, he was as well loved and respected among Protestants as among his own co-religionists... Many now priests, lawyers, college rectors, legislators, many able and useful citizens made their first higher studies under him. The good influence he exerted on his pupils even in later years, was astonishing. They were still to him his 'dear boys' of former years, they were priests, lawyers or even editors. ${ }^{29}$
\end{abstract}

On Wednesday, June 16, 1915 St. Jerome' College celebrated its golden jubilee with great pomp and ceremony. In the course of the many speeches which were given frequent allusions were made to Fr. Louis' vision but it was the alumni present who testified to the success of Fr. Louis. Among those attending the alumni reunion we find the names Lang, Krug, Winterhault, and Motz each one a leading Catholic layman in Berlin. It was William Motz who, in his Toast to the College and the Alumni, most clearly reflected the theme of Catholic leadership:

'...we know and feel that the founding of St. Jerome's College was worthwhile, and that the good accomplished by Father Louis is greater far than falls to the lot of most men. Still all the success would be in vain, if St. Jerome's College could not point with pride to its product, the Alumni... In the professional and business world, ...in almost all higher callings of life graduates of St. Jerome's College have attained success and prominence, because their College training was founded on sound Christian principles. ${ }^{30}$

Motz himself was an excellent example of the Alumnus of whom he spoke. As editor of the Berliner Journal his editorial policies were shaped by the education he had received at St. Jerome's under Fr. Louis. In 1911 Julius Funcken, the last survivor of the four Funcken

${ }^{29}$ Cited in The Bee, VII :1 (April, 1905), pp. 23-24; incorrectly dated April 15, 1900.

${ }^{30}$ The Schoolman, XVII:4 (June, 1915), pp. 230-31. 
brothers, wrote to Father Theobald Spetz asking him to pass on to Motz his family's gratitude for the Journal in which, he said, 'we believe we are not mistaken when we see Louis' views in the trend of the paper.' ${ }^{31}$ The Berliner Journal was openly anti-conservative and while dedicated to the use of German in church, home and school and the civic duty of German-Canadians it was also not reluctant to criticize harshly anti-liberal tendencies in Germany and its growing Prussian militarism. All of these themes were espoused by Louis and urged on the Roman Catholics of Berlin, and Waterloo County.

In addition to his enormous contribution to the German-Catholics of Waterloo County through the instruction of lay leaders, Fr. Louis was also instrumental in two allied areas which also contributed to the rapid emergence of the Catholics as a coherent and important group. Since the focus of this paper was on the vision of Fr. Louis Funcken and its results in the area of lay leadership I will discuss these areas briefly although they deserve and hopefully, at a later date, will receive further study.

Essential to the establishment of any religious group is the presence of a clergy. Fr. Eugene Funcken had been acutely aware of the need for a German-speaking clergy and it was Fr. Louis' College which would be the instrument to produce this. While Louis always insisted that his institution not be labelled a seminary it was always his hope and expectation that, given the nature of the College and its atmosphere, vocations to the priesthood would be forthcoming. His hopes were not in vain. During his tenure alone about one hundred of his students were ordained. His success at encouraging vocations led Bishops Carbery (1883-89) and Dowling (1889-1924) to appoint Fr. Louis diocesan examiner of the clergy. Thus, even those priests who did not enter the diocese by way of the College would still be subject to some extent to Fr. Louis' influence. By the time he left the College in June of 1889 five of his students had returned as priests to take up teaching positions at St. Jerome's passing on the values and traditions of their mentor. With these facts in mind the observation of Wm. Motz that, 'Nearly every priest of Hamilton diocese is a St. Jerome's graduate,' ${ }^{32}$ takes on great significance. It can be said that in 1915, when this remark was

\footnotetext{
31 Archives of the Congregation of the Resurrection in Ontario. Papers to Fr. Spetz.

32 “"Toast to the College and Alumni", The Schoolman, p. 230.
} 
made, there was not only an indigenous clergy but a clergy which, to a greater or lesser extent had the stamp of Fr. Louis upon it. Although no study has yet been done of clerical views and opinions in this period the comments of priests in letters to Louis and other addresses indicate a significant influence.

Another aspect of Fr. Louis' career which deserves more attention than can be given here was his ecumenical spirit, although he would not have called it such. From the very beginning non-Catholics were admitted to the College and while this practice probably originated in a need for students it soon became a common practice. In 1890 J.O. Rittinger was unanimously chosen as President of the Alumni Association and Conrad Bitzer was acclaimed as Treasurer, and they, both Lutherans, were appointed to the Father Louis Memorial Committee. Rittinger as editor of Die Glocke wrote of Fr. Louis: 'Honest and sincere in his convictions, tolerant towards his fellow Christians of other denominations, he was as well loved and respected among Protestants as among his own co-religionists.' ${ }^{33}$ Included among Fr. Louis' non-Catholic students were also Herbert Bowlby who was not only the school physician but became mayor in 1901 as Bitzer had in 1892; Bowlby was an Anglican. The Mennonites were represented by Ezra Eby who became a teacher and an author. Each of these men achieved prominence and were held in great respect by the population.

The respect men such as these had for Louis was reflected in the general acceptance of Roman Catholics in general. This, of course, made it that much easier to move into the social and political mainstream of Waterloo County life. The harmony which existed among the various religious groups was not only a consequence of their common German heritage but also of the vision which Fr. Louis had that being a Catholic did not mean staying aloof from society but, on the contrary, demanded the exercise of industry, loyalty, and civic-mindedness.

When Father Louis Funcken arrived in Waterloo County he found a Catholic community composed of agricultural and skilled labourers and a community which was virtually priestless. In the quarter of a century of his labours the Catholic community took on a new appearance and became a vital force in the region. His plan, his dream had come to be; unfortunately his untimely death at the age of 57 on January 30,1890

${ }^{33}$ The Bee, p. 23. 
denied him the opportunity to savour it. John Rittinger reported this sad event with these words: 'It is our sad duty to-day to report the death of a man whose name will never be forgotten, not only by members of his own religious faith, but by all and particularly the Germans of Canada.' ${ }^{34}$ No doubt, Father Louis would have been pleased.

${ }^{34} \mathrm{Ibid}$. On February 6, 1890, The Berliner Journal ran a two-column front page obituary of Fr. Louis. On February 27 it published "Probably his last letter" to August Kaiser in Detroit only to be followed by "his last letter" sent to Theobald Spetz dated January 11. Included in the edition of the 27th was the description of Fr. Louis' final days and death based on information provided by Fr. Ladislaus Witkowski who had been present. 